\title{
AQUÉM E ALÉM DE O NEGRO NO FUTEBOL BRASILEIRO: UMA RELEITURA DA OBRA DO JORNALISTA ESPORTIVO MÁRIO FILHO ENTRE OS ANOS 1940 E 1960
}

\author{
Below and beyond O negro no futebol brasileiro: \\ $A$ reinterpretation of the work of sports journalist \\ Mário Filho between the 1940s and 1960s
}

Bernardo Borges Buarque de Hollanda ${ }^{1}$

\begin{abstract}
RESUMO
$\mathrm{O}$ artigo propõe um novo enquadramento do livro principal do jornalista esportivo Mário Filho, O negro no futebol brasileiro (1947). Sustenta-se que só é possível entender os argumentos internos deste, por assim dizer, "clássico" do memorialismo futebolístico à luz do conjunto da obra do escritor, especialmente o livro que o antecede, Histórias do Flamengo (1945), usualmente desconsiderado pelas análises acadêmicas. A revisão deste livro comemorativo do cinquentenário do clube carioca permite identificar as linhas mestras, tanto em forma quanto em conteúdo, da narrativa que consagraria Mário Filho dois anos depois. Junto a esse cotejo, acompanha-se igualmente o impacto de ambos os livros no decềnio de 1960, quando, emulados pela crítica jornalística e literária, ambos os trabalhos assistem a reedições, sendo relançados por editoras de peso no cenário cultural e intelectual de então. Conclui-se com a reafirmação da necessidade de uma releitura de conjunto de Mário Filho, a fim de entender com mais acuidade não só o caráter prolífico de sua produção bibliográfica ao longo das décadas, como também as etapas de construção de um projeto jornalístico-letrado que se somava à decantação da tradição "nacional-popular" no Brasil dos anos de 1940 e 1960.
\end{abstract}

\begin{abstract}
This article proposes a new framework for the principal book of sports journalist Mário Filho, O negro no futebol brasileiro (1947). It is argued
\end{abstract}




\begin{abstract}
that the internal arguments of this book, which is considered a "classic" of Brazilian football memory, can only be understood considering the writer's whole body of works, especially Histórias do Flamengo (1945), which predates it and is usually disregarded in academic analyses. Reviewing this book, a celebration of Flamengo's 50th anniversary, allows us to identify the main narrative lines, both in form and content, that would enshrine Mário Filho two years later. Concurrently to this comparison, the impact of both works in the 1960s is also analyzed, a moment when journalistic and literary critics led to reissues of both works, being issued by renowned publishers in the cultural and intellectual scenario of the period. The conclusion is a reaffirmation of the need for a rereading of Mário Filho's body of works, to more accurately understand not only the prolific character of his bibliographic production over the decades, but the steps of construction of a journalistic and literate project that was added to the decanting of the "national-popular" tradition in Brazil during the 1940 s and 1960 s.
\end{abstract}

\title{
Introdução
}

O propósito do presente artigo é oferecer um exame pontual da obra do jornalista Mário Rodrigues Filho (1908-1966)2 , levantando um questionamento específico de sua fortuna crítica. A análise volta-se não apenas para a análise da estrutura interna e dos argumentos centrais de seu livro mais importante e consagrado, O negro no futebol brasileiro (1947), tema abordado com frequência pela literatura especializada, como especialmente pelo destaque de uma outra estratégia analítica. É sabido que os estudos sobre Mário Filho vêm-se avolumando nos últimos anos, com destaque para Fátima Antunes (2004), Marcelino Rodrigues da Silva (2006), Denaldo Souza (2008), André Mendes Capraro (2011) e Fernanda Ribeiro Haag (2014), com uma riqueza de novas informações e interpretações. Nos limites espaciais deste artigo, vamos nos cingir à historiografia dedicada a questionar de modo mais frontal os fundamentos narrativos de $O$ negro no futebol brasileiro.

2 Embora o jornalista pernambucano grafasse seu primeiro nome sem acento, assinando Mario, optamos aqui por seguir as convenções ortográficas atuais, utilizando o acento e grafando Mário. 
Visa-se a seguir enquadrar Mário Filho em um horizonte mais amplo de escrita e de projeto jornalístico-letrado, discorrendo sobre o contexto em que se produziu sua obra, a recepção da Academia a seu trabalho e, em especial, a ênfase na publicação de uma gama de livros do autor, via de regra desconsiderados, concernentes à história e à memória do futebol brasileiro no século XX. Dadas as limitações de espaço na produção de um artigo científico, do conjunto de escritos será pinçado um livro - Histórias do Flamengo (1945) - para cotejo reflexivo com a publicação mais conhecida, O negro no futebol brasileiro.

Procura-se inserir seu livro mais conhecido no interior da década em que suas publicações e edições tiveram mais proeminência no cenário editorial e esportivo brasileiro. Trata-se dos anos 1940, mais precisamente do período entre 1943 e 1949. Esta década avulta em importância na história do futebol brasileiro em virtude da realização da Copa do Mundo da FIFA no país, evento que foi um dos fatores contribuintes para a publicação de uma tetralogia do futebol. Durante este decênio, Mário Filho colige crônicas diárias e escritos de jornal e tem por iniciativa materializá-los sob a forma de livros, um total de quatro naquela década, lançados em um intervalo regular de dois anos. A série está disposta na seguinte sequência cronológica: Copa Rio Branco 32 (1943), Histórias do Flamengo (1945), O negro no futebol brasileiro (1947) e Romance do football (1949).

Já nos anos 1950, por razões desconhecidas, verifica-se um interregno nas publicações sob a forma de livros por parte de Mário Filho. Todavia, sua colaboração em periódicos e jornais esportivos mantém-se intensa e ininterrupta. Se a primeira fase de sua obra corresponde aos anos 1940, a segunda fase diz respeito à década de 1960 e compõe-se de três livros. Dois deles - O negro no futebol brasileiro e Histórias do Flamengo são reedições, ampliadas e atualizadas de maneira substantiva, e vêm a lume em 1964 e 1966, respectivamente ${ }^{3}$.

Além desses, o terceiro e inédito livro da segunda fase intitulase Viagem em torno de Pelé, biografia lançada em 1963, na esteira do bicampeonato mundial conquistado pela Seleção Brasileira em 1958, na Suécia, e em 1962, pelo Chile. Um quarto projeto de livro, intitulado Interpretação do futebol, não chegou a se concretizar antes de sua morte,

3 Histórias do Flamengo data do ano de falecimento do jornalista. A segunda edição teve direito à noite de autógrafos, que guarda um registro audiovisual, gravado pelo cinejornal Canal 100, dirigido por Carlos Niemayer. 
ainda que aparecesse anunciado nas páginas e nas orelhas de seus livros dos anos de 1960.

A produção bibliográfica de Mário Filho é, não obstante, ainda mais ampla e não se restringe apenas aos esportes. O jornalista tinha especial interesse pelo terreno das letras e da literatura, sendo contemporâneo e próximo da geração do modernismo e do regionalismo brasileiro. Além de uma biografia sobre o pintor Cândido Portinari ${ }^{4}$, em 1966, em sua mocidade o jornalista havia se lançado na ficção, no ano de 1927, com Bonecas.

Nos idos de 1950, escreveu mais três obras literárias: Senhorita, Um dia de trabalho e Dezenove. Sua substantiva produção ficcional culminou em 1964 com um romance intitulado O rosto. Desde 1949, porém, mostrava inclinação no terreno da ficção esportiva com seu Romance do football. Ainda que a alusão romanesca esteja presente apenas no título, sua utilização parece emblemática de um projeto letrado ambivalente. Saliente-se que a temática que só encontra antecessor no livro de outro jornalista esportivo, o ítalo-paulista Thomaz Mazzoni, Flô, o maior goleiro do mundo (1940) e no romance do amigo José Lins do Rego, Água-mãe (1941) (RORIGUES FILHO, 1949, 1965 e 1966).

Das obras acima mencionadas, Bonecas e Senhorita não possuem referências bibliográficas, já que as únicas informações encontradas proveem de Mário Neto, numa seção constante da quarta edição do livro de seu avô, $O$ negro no futebol brasileiro (2003). Quanto a Um dia de trabalho e Dezenove, apenas localiza-se referência indireta por meio da obra Romance do football, sendo anunciados em suas páginas como dois romances no prelo. Não é possível saber, pois, de maneira definitiva se chegaram a ser editados. A consulta à Biblioteca Nacional verificou a inexistência da publicação destes dois sob a forma de livro, donde infere-se que a resposta mais plausível seja a negativa e restem deles apenas manuscritos.

Traçada brevemente acima a cronologia mais ampla de sua bibliografia, tanto a esportiva quanto a literária, que evidenciam o caráter prolífico de sua produção escrita, apresenta-se a seguir o recorte do presente artigo, com uma estrutura que se subdivide em duas seções principais. A

4 A família de Mário esteve sempre envolvida no círculo literário-artístico. Um de seus irmãos, Milton Rodrigues, era cineasta e dirigia o cinejornal "O esporte em marcha", ao passo que Augusto Rodrigues era pintor e gravador. Mário conhece Portinari por intermédio do irmão Roberto Rodrigues, também artista plástico, mas precocemente falecido, em fins dos anos 1920. 
primeira tem por objetivo introduzir o estado da arte da fortuna crítica e das interpretações acerca da trajetória de Mário Filho.

A fonte principal para esses dados provém do jornalista Ruy Castro, que, no decorrer os anos 1990, foi responsável por três antologias de crônicas para a editora Companhia das Letras: O sapo de Arubinha, A pátria de chuteiras e $\dot{A}$ sombra das chuteiras imortais (CASTRO, 1995, 1994a e 1994b). A primeira colige crônicas esparsas de Mário Filho, ao passo que a segunda e a terceira são dedicadas ao irmão, Nélson Rodrigues, cujos relatos jornalísticos são peças importantes na construção da imagem do primogênito.

Pode-se dizer que as três antologias reposicionaram Mário Filho no mercado editorial brasileiro e colocaram em contato as novas gerações de leitores com as crônicas futebolísticas do jornalista pernambucano. As antologias foram publicadas na esteira do lançamento da biografia de Nelson Rodrigues, irmão caçula de Mário. O extenso relato biográfico de Ruy Castro acerca de Nélson dedica páginas significativas ao recuperar certa leitura laudatória do caráter inovador e empreendedor legado pela imagem de Mário Filho.

Repiso também, como fonte de consulta, a minha própria dissertação de mestrado, defendida em 2003, que examinou as crônicas esportivas de José Lins do Rego, publicadas entre 1945 e 1957 no Jornal dos Sports, periódico de propriedade de Mário Filho. À época da pesquisa, procurei enquadrar as crônicas de Lins do Rego lado a lado com o debate literário do modernismo brasileiro e, em particular, com o ensaio social de Gilberto Freyre e com o projeto cronístico de Mário Filho. Se as trajetórias individuais de Lins do Rego Freyre e Rodrigues Filho são irredutíveis entre si, propus a construção de uma visão a respeito destes três autores de origem nordestina - o romancista, o sociólogo e o jornalista - cujo intercâmbio e cuja amizade chegam a dificultar o discernimento das ideias exclusivas de cada um deles.

Finalmente, ainda na primeira seção deste artigo, apresento a perspectiva crítica desenvolvida entre o final dos anos 1990 e o início dos anos 2000 por pesquisadores acadêmicos acerca do assim chamado "clássico" O negro no futebol brasileiro. Estes autores, em suas dissertações de mestrado, teses de doutorados e artigos científicos, propuseram um debate com questionamentos a determinadas premissas do memorialismo esportivo contido na obra magna de Mário Filho, muitas das vezes incorporado de maneira acrítica pelos historiadores e cientistas sociais, dessa sorte, classificados como "novos narradores acadêmicos", conforme a polêmica tese esposada por Antônio Jorge Soares. 
Já a segunda seção detém-se no período histórico dos anos 1940, quando do aparecimento da primeira edição de $O$ negro no futebol brasileiro, e elege um dos livros publicados por Mário Filho para exame. O livro eleito para análise é Histórias do Flamengo, publicado em 1945, data comemorativa do cinquentenário de fundação do Clube de Regatas do Flamengo. A hipótese postula a existência de encadeamentos argumentativos de Histórias do Flamengo (1945) que se desdobram em O negro no futebol brasileiro (1947), a exemplo da composição estrutural do livro e dos critérios para seu interesse por a tematização daquele clube em específico. Entende-se que a contextualização do período e o cotejo das duas obras dão elementos narrativos para a compreensão de sua obra consecutiva e mais afamada.

Enquanto redigia Histórias do Flamengo, que viria a ter igualmente quatro edições em sua história editorial (1945, s/d, 1966 e 2014), Mário Filho também publicava as crônicas da coluna do jornal $O$ Globo, "Da primeira fila", base para seu futuro livro. Essa começara a ser escrita em 1942 e se tornaria pública em 1947, com a primeira edição de $O$ negro no futebol brasileiro. Outra razão reside na semelhança do trajeto dos livros: publicados nos anos 1940 pela editora Pongetti, conhecem nova edição nos anos 1960. O negro no futebol brasileiro é relançado pela importante Editora Civilização Brasileira ${ }^{5}$, casa editorial associada ao nome de Ênio da Silveira que, à época, foi muito marcado pela militância cultural de esquerda, ao passo que História do Flamengo é reeditado pela editora Record, também reconhecida como de ponta no âmbito editorial.

Destarte, são obras coetâneas, que permitem reconhecer traços comuns de seu projeto de escritor da memória do futebol "nacional" - modo metonímico como, não só, Mário Filho pensava o lugar da cidade do Rio de Janeiro à época -, em meados do século XX.

\section{O debate jornalístico-acadêmico em torno de Mário Filho}

Em uma definição geral, considera-se Mário Filho um empresário e um jornalista esportivo, que se caracterizou por ser promotor, militante

5 A importância intelectual editorial de Ênio Silveira encontra-se bem explorada em artigo recente pelo historiador Cristiano Couto (2012). 
e ideólogo dos esportes no Brasil do século XX. Parte dessa compreensão deve-se à regularidade da publicação seus livros ao longo da década de 1940, sendo o mais importante deles Onegro no futebol brasileiro (1947), publicado pouco tempo depois do anúncio da realização do IV Mundial da Fifa no Brasil, em 1950. O livro ambiciona recontar a história do futebol brasileiro da primeira metade do século passado, jungindo suas lembranças pessoais a uma pesquisa inovadora, baseada em fontes orais, com antigos jogadores.

Além desse livro, o conjunto de seus escritos, ficcionais e memorialísticos, acompanha paripassu sua atuação empresarial no jornalismo esportivo. Oriundo de uma família de jornalistas pernambucanos, radicados no Rio de Janeiro no início do século XX, Mário Filho encampou o Jornal dos Sports em 1936 (ANTUNES, 1999, p. 107), com o apoio financeiro dos amigos Arnaldo Guinle, Roberto Marinho e José Bastos Padilha. Este último foi o presidente o Clube de Regatas do Flamengo que, entre 1933 e 1937, apoiou Mário Filho na campanha contra o amadorismo até então vigente, em favor do profissionalismo, da presença de jogadores negros e do processo de popularização do futebol no Rio de Janeiro, capital da República.

A atuação de Mário Filho no processo de criação de um campo autônomo para o jornalismo esportivo no Rio de Janeiro, mediante a valorização de um gênero até então tido como menor pela imprensa, foi considerada decisiva e bastante frisada nas páginas biográficas indiretas de Ruy Castro. Como inexiste biografia consagrada a Mário, amparamo-nos naquela dedicada ao irmão Nelson Rodrigues. O surgimento de um modelo de reportagem esportiva na década de 1930, passando a contar com um espaço privilegiado nos periódicos da cidade e, em 1936, com um próprio jornal inteiramente dedicado ao tema, o Jornal dos Sports - a suceder os tradicionais tabloides esportivos -, acompanhava a profissionalização e a oficialização da presença de jogadores negros nos clubes de elite do Rio de Janeiro. Mário Filho atuava nesse sentido com suas atenções centradas na formação de um público de massa e de grandes espetáculos esportivos.

Ao lado das mudanças visuais e técnicas por que passava o jornalismo esportivo sob o crivo de Mário Filho, a crônica procurava também alcançar uma forma mais dinâmica e interativa de comunicação e ia ao encontro desse público leitor por meio de uma série de inovações linguísticas.

Em um ensaio sobre o jornalista Mário Filho, que se baseia por sua vez em informações do livro do jornalista Ruy Castro sobre Nélson Rodrigues, o antropólogo José Sérgio Leite Lopes (1994, p. 68) evidencia a adoção de uma linguagem mais coloquial na crônica esportiva desse período, 
retirando-a da formalidade dos inúmeros termos em inglês e aproximando-a das expressões correntes dos torcedores nos estádios. A modernização da crônica esportiva caracterizava-se pela implantação de uma nova linguagem e de uma nova narrativa, assim como pelo estabelecimento de uma nova relação entre o cronista e o leitor. Esta relação se prolongava muitas vezes por meio de um contato direto nas ruas, nos bares e nos estádios ou por meio de cartas, telegramas e até telefonemas, o que influenciava e trazia repercussões imediatas para os temas da crônica.

Nesse sentido, segundo palavras encomiásticas de Nélson Rodrigues, seu irmão Mário Filho havia empreendido uma verdadeira revolução jornalística na área esportiva, com uma nova concepção sobre o estatuto da imagem e da diagramação, bem como com uma renovada inserção de títulos e subtítulos, de manchetes e legendas nas páginas de esportes.

Era ainda no terreno da linguagem que Mário Filho se destacava com mais vigor. A partir de 1926, quando realiza sua pioneira entrevista de meia-página com o goleiro Marcos Carneiro de Mendonça - entrevista esta que se desdobraria nos anos de 1930 em uma série de entrevistas realizadas no café Nice, da galeria Cruzeiro, próximo à redação de $O$ Globo, onde se reuniam torcedores e jornalistas, jogadores e até compositores populares, como Noel Rosa (CASTRO, 1992, p. 131-132) -, Mário Filho passa a promover diariamente o enriquecimento do vocabulário da crônica esportiva, desfazendo-se do tom solene que então a caracterizava e trazendo para o espaço do jornal a "gíria libérrima" (RODRIGUES FILHO, 1995, p. 8) dos torcedores.

Por conseguinte, sem entrar na discussão a respeito do sentido revolucionário, renovador ou meramente reformista de Mário Filho em relação à linguagem esportiva, é importante frisar ao menos, sob sua influência, uma substantiva inflexão nos rumos da crônica esportiva após o decênio de 1930, conforme pontuadas por Nelson Rodrigues, Ruy Castro e José Sérgio Leite Lopes.

A par da incorporação de parcela considerável da linguagem coloquial e da oralidade popular característica do mundo do futebol, a criação de uma crônica esportiva nos moldes preconizados pelo jornalismo de Mário Filho na década de 1930 estimulava o estabelecimento de uma relação dialógica entre o cronista e o leitor. A crônica esportiva constituía assim um espaço mais direto de mediação e de interlocução entre esses dois polos integrantes do universo esportivo e dava oportunidade para a troca de 
contato do cronista com uma pluralidade de visões acerca de suas matérias e de seus comentários sobre as partidas de futebol.

Em âmbito nacional, Mário Filho trouxe para suas lides o caso singular de uma cronista esportiva mulher, Florita Costa. Esta, por sua vez, vinha a ser esposa de Flávio Costa, o famoso técnico do Flamengo, do Vasco da Gama e da Seleção Brasileira. Vale incluir ainda os prestigiados dirigentes das entidades desportivas nacionais, como João Lyra Filho (CND), Mário Polo (CBD), José Lins do Rego (CBD) e Vargas Netto (FMF) ${ }^{6}$, este último também homem de letras e sobrinho de Getúlio Vargas.

Como forma de reposicionamento político após a Revolução de 1930, quando o jornal do pai foi empastelado, a presença desse staff dirigente conferia um peso ainda maior para a promoção da crônica esportiva e para a efetivação de um canal mais direto de comunicação não só entre o torcedor e o cronista, como entre o torcedor e os principais representantes políticos do futebol brasileiro.

Importa realçar, no recorte e na delimitação proposta para este artigo, o ponto central de que esse projeto de crônica esportiva pautado por Mário Filho aos poucos vai-se tornando hegemônico nos periódicos cariocas. Mais do que implicações quanto à dominação política, cumpre verificar que, do ponto de vista do desenvolvimento de uma crônica esportiva moderna, estes cronistas encontravam oportunidade para forjar um estilo narrativo próprio, para refletir de forma livre sobre os temas mais variados e para exprimir alguns aspectos de sua própria personalidade.

Não obstante, pesquisadores de São Paulo têm procurado relativizar o pioneirismo de Mário Filho na invenção de uma crônica esportiva moderna. Sendo endossado pelo antropólogo Luiz Henrique de Toledo (2002), José Renato de Campos Araújo (2000) procura mostrar de que maneira na imprensa paulista, e em especial no jornal O Estado de São Paulo, já havia desde pelo menos 1914 uma cobertura regular e sistemática dos matches por parte da crônica esportiva da cidade.

Assim, Campos Araújo questiona o esquema redentor montado por Nelson Rodrigues na interpretação da obra de seu irmão, segundo o qual, à crônica objetiva, fria e impessoal das primeiras décadas do século, limitada à informação, sobrepunha-se, então, nas décadas de 1930, 1940 e 1950, uma

6 Siglas correspondentes a: Conselho Nacional de Desportos, Confederação Brasileira de Desportos e Federação Metropolitana de Futebol. 
crônica esportiva de cunho pessoal, abrindo margem para a narração, para a manifestação da subjetividade do cronista e para a formação de um estilo característico de cada um deles.

Assim, com o tempo, a obra de Mário Filho tornou-se paradigmática do memorialismo para a historiografia do futebol brasileiro. A obra mais conhecida de Mário Filho, O negro no futebol brasileiro (1947), passou também a ser associada desde então à versão esportiva do livro Casa-Grande \& Senzala (1933), de Gilberto Freyre. Em decorrência disso, a mesma crítica que se faz a Freyre - suposto arauto da "democracia racial"7 - também se encontra em relação ao jornalista pernambucano, qual seja, a de que Mário Filho defende a tese segundo a qual a inserção social do negro no futebol profissional a partir da década de 1930 se deu de forma democrática, dúctil, harmoniosa.

Assim, antes de examinar tal crítica, vale ponderar que a construção do prestígio de sua obra não se deu de fato de forma isolada. Em dados coligidos na pesquisa de mestrado $O$ descobrimento do futebol, apontei como os prefácios do escritor José Lins do Rego e do sociólogo Gilberto Freyre servem de chancela intelectual às obras de Mário Filho. Em 1943, José Lins do Rego prefacia Copa Rio Branco 32, enquanto em 1947, a pedido do próprio José Lins do Rego, é Gilberto Freyre quem assina o prefácio de $O$ negro no futebol brasileiro. O romancista paraibano e o sociólogo pernambucano dão respaldo às qualidades e aos dotes literários do jornalista, ao mesmo tempo em que se abeberam dos aspectos considerados mais relevantes dessa tentativa serial de escrever uma historiografia quase romanceada do futebol brasileiro.

Com base em Mário Filho, José Lins do Rego e Gilberto Freyre viam dois fenômenos originais surgidos no seio do futebol brasileiro: a vigência do legado étnico negro e a incorporação da música na forma de se jogar o futebol. Depois de falar da "democratização" do futebol, Mário Filho assim se refere: "O povo descobrindo, de repente, que o futebol devia ser de todas as cores, futebol sem classes, tudo misturado, bem brasileiro" (RODRIGUES FILHO, 2003, p. 69).

José Lins do Rego, além de prefaciador da primeira obra esportiva de Mário Filho em 1943, Copa Rio Branco 32, havia sido o intermediário

7 Ressalve-se que Gilberto Freyre não emprega a expressão "democracia racial", mas antes "democracia social". Não convém aqui entrar nos pormenores da contenda, já exaustivamente explorada pela Academia. 
que apresentara Gilberto Freyre ao jornalista pernambucano, tornando possível a realização daquele prefácio a $O$ negro no futebol brasileiro, livro que era anunciado em 1947 no Jornal dos Sports a um só tempo como obra de literatura e como obra de sociologia.

No ano seguinte, em 1948, o livro seria promovido ainda com a publicação de artigos de intelectuais como o historiador Nelson Werneck Sodré, a antropóloga Maria Isaura Pereira de Queiroz, a romancista Rachel de Queiroz, o poeta Jorge de Lima e o crítico Olívio Montenegro, contribuindo para estatuir um duplo valor - científico e literário - à obra de Mário Filho. Tal fato teria continuidade na segunda edição do livro, em 1964, com a apresentação e a legitimação do folclorista baiano Edison Carneiro (MONTENEGRO, 15/07/1948, p. 5; SODRÉ, 08/07/1948, p. 5; QUEIROZ, 24/07/1948, p. 5; CARNEIRO, 1964).

A indeterminação de gênero que se atribuía à obra de Mário Filho, com sua combinação de história e romance, de sociologia e crônicas pitorescas, é um elemento que chama a atenção na medida em que revela uma mesma ambiguidade já cultivada por Gilberto Freyre na construção da representação de sua própria imagem como escritor. Completando o liame entre Mário Filho e Gilberto Freyre, José Lins do Rego era o terceiro vértice que possibilitava a compreensão do conjunto de ideias sobre o futebol que estavam sendo concatenadas e compartilhadas por esta tríade intelectual.

Um exemplo constitui alentada apreciação crítica ao, à época, recémlançado livro de Mário Filho, O romance do football, José Lins do Rego dedica-se quase que tão-somente a frisar os dotes de narrador e as qualidades estilísticas - com nuances de técnica cinematográfica - do jornalista pernambucano. Mário Filho era assim tanto um narrador tradicional, pelo conteúdo, quanto um narrador moderno, pela forma, que transpassava os limites do realismo e do naturalismo e aproximava a linguagem da literatura à linguagem do cinema, conforme desde a década de 1930 já faziam alguns dos melhores romancistas norte-americanos, como John dos Passos, Ernest Hemingway e John Steinbeck:

"Outro livro de Mário Filho que tomou para substância e conteúdo humano o football. É que arrancou dessa prática esportiva a sua mais romanesca particularidade. Mário Filho é um homem que tem o dom da narração, de contar o que sabe e o que imagina, como rio que corre para o mar. Os fatos, os incidentes, os choques, 
as alegrias e as dores dos seus personagens se apresentam ao leitor, como um conto ou história de Trancoso, no mais simples e mais patético narrar.

Se é preciso carregar nas cores, para que a figura surja, no seu melhor pitoresco, o escritor Mário Filho não recorre aos retratos naturalistas, onde até os botões do casaco estejam no seu lugar. Nada. O escritor adota a técnica cinematográfica da câmara, e nos põe em contato com as suas personagens, no movimento da vida.

Neste sentido, a história de Jaguaré é uma obra-prima. O herói burlesco, o palhaço das exibições, de fleuma e acrobacia, o homem que brincava com os nervos das multidões, que fizera do football uma originalidade de circo, corre no filme de Mário, desde os dias de malandragem, com o gorro de marinheiro na frente da cabeça e a camisa por fora das calças, até os dias gloriosos da França ou das vitórias espetaculares do Vasco, à morte a pauladas, como se fosse um cachorro, danado, numa cidade do interior de São Paulo. O poder descritivo de Mário Filho atinge ao seu maior volume, ao vigor trágico, na narrativa que ele faz do desastre de Teresópolis, com o trem do Fluminense. O fato, nu e cru, cria um corpo de acontecimento empolgante. $\mathrm{O}$ trem a despencar da ladeira abaixo. E depois os gemidos, o sangue, os gritos, na desordem dos carros esfrangalhados, da máquina despedaçada no abismo. E morre Py, no silêncio da viagem lúgubre, com a presença de Vinhais, como guarda do velório. Esta é a grande página de Mário Filho, o seu maior poder de romancista, que sabe arrancar da realidade as suas seivas vitais.

'O romance do football' apresenta também o burlesco, a paixão que supera o ridículo como no caso daquele Guimarães, carona que queria, à força, um permanente do clube para poder exibir a sua importância de convidado credenciado.

Reli todo o livro de Mário Filho com o mais vivo interesse. E o que mais caracteriza as suas qualidades de narrador é a superioridade de sua natureza humana, a nota poética de que anda sempre nos fatos que ele isola para a sequência de seus filmes. Os homens de Mário Filho, desde os mais humildes aos mais graúdos, são criaturas que nos interessam, e nos comovem, homens que se entregam à paixão de sua partida de football para se comportarem à vontade dos acontecimentos, como folha ao vento". (REGO, 7/12/1945, p. 5). 
A relação do futebol com a literatura é o ponto de convergência entre Mário Filho e os autores egressos do movimento modernista, particularmente os nordestinos, como Lins do Rego. Atente-se nessa relação o fato importante de que Mário Filho e José Lins do Rego haviam se conhecido no início dos anos 1940 na redação do jornal $O$ Globo e em 1945, Mário Filho convida o romancista a colaborar como colunista esportivo de Jornal dos Sports, aonde mantém coluna por 12 anos, com mais de 1.500 publicações. A subordinação entre empregador e empregado não deve ser, neste sentido, desconsiderada na legitimação de Mário Filho pelo escritor Lins do Rego, então no auge de seu prestígio literário ${ }^{8}$.

Se desde pelo menos o final dos anos de 1920 o jornalista Mário Filho acalentava o projeto literário de romancista, projeto este iniciado em 1927 com a obra Bonecas e finalizado em 1966 com A infância de Portinari, podese dizer que tal proximidade se dava de igual forma no campo da linguagem. Nele se processavam uma série de transformações que tinham como objetivo encurtar a distância entre o escritor e seus leitores, num grau análogo ao que era preconizado pelos escritores modernistas, para quem eram fundamentais a incorporação de termos coloquiais e a fusão da linguagem escrita com a linguagem oral.

A contrapelo, depois de enaltecida, a suposta ambivalência entre a literatura oral e a história, entre o ficcional e o factual, entre o mito e a ciência, passou a render ao Autor, do final dos anos 1990 em diante, uma série de críticas por parte de cientistas sociais. O estreito vínculo ao poder político, econômico e esportivo do diretor do Jornal dos Sports e de parte considerável de sua equipe de cronistas desencadeou mais questionamentos de parte de cientistas sociais e historiadores contemporâneos. Leonardo Affonso de Miranda Pereira (2001) e Antônio Jorge Soares (1998) foram dois dos maiores "desconstrutores" dos pressupostos de sua obra e procuraram relativizar a ação de vanguarda e supostamente progressista de Mário Filho.

Por um lado, a desconstrução se dava na medida em que, segundo Pereira e Soares, cada um à sua maneira, tal visão cristaliza um viés personalista ou paternalista na abordagem das transformações do futebol

8 Veja-se a propósito a instigante análise da produção cronística de Lins do Rego feita por André Capraro (et alli) no ano de 2016, em particular a publicação em livro das crônicas do romancista, Flamengo é puro amor (2001). 
brasileiro como um todo, creditando-se a um único jornalista feitos que se integram a um processo coletivo, histórico e social mais amplo.

Por outro lado, a crítica estabelecia-se na proporção em que Mário Filho procurava elaborar um cânone discursivo e, logo, de elite, em torno do caráter "popular" para ele imanente e emancipador da trajetória do futebol brasileiro, com o advento do profissionalismo na década de 1930. Este discurso "oficial" é possível aduzir, também se perpetuava na área da crônica esportiva com a escolha, para ocupar estas funções, de dirigentes dos principais clubes e das mais importantes representações desportivas do país.

Segundo o pesquisador Antônio Jorge Soares, Mário Filho acabou por produzir uma visão edulcorada da história do futebol no Brasil, num tipo de narrativa que se assemelha à forma do conto folclórico dissecado por Vladimir Propp e que, poderíamos também acrescentar, remete à imagem do narrador tradicional e do contador de histórias sugerido por Walter Benjamin.

O historiador Leonardo Affonso de Miranda Pereira, por sua vez, enfatizou sua contraposição à tese esposada pelo jornalista Mário Filho, segundo a qual a passagem do futebol de esporte elitista a esporte popular se deu de forma linear e unívoca, promovendo de forma democrática a ascensão social de negros e mestiços nos esportes e, por extensão, na sociedade brasileira. Neste sentido, um dos méritos da obra do historiador Leonardo Affonso de Miranda Pereira é o alargamento do escopo discursivo aos diversos atores envolvidos no universo esportivo e que não se restringiam ao discurso da esfera oficial do poder futebolístico, tal como ficou centralizado na figura de Mário Filho.

Sem negar a validade de muitos pontos da periodização estabelecida pelo jornalista, Leonardo Pereira procuraria demonstrar a polissemia do jogo e as diversas possibilidades de percepção da sua apropriação entre outros segmentos da população carioca. Os pontos de vista dos trabalhadores e dos operários eram assim considerados no intuito de mostrar como diferentes práticas e tradições populares impregnaram o futebol de significados distintos daqueles preconizados pelo projeto oficial letrado, fator que gerou embates e disputas em torno dele.

Em sintonia com a perspectiva da escola marxista inglesa das décadas de 1950, 1960 e 1970, tendo à frente Christopher Hill, Edward Palmer Thompson e Eric Hobsbawm, Pereira frisa a condição ativa da cultura operária dos trabalhadores da bola, partícipes ativos e não apenas tábula rasa do processo que transformou o futebol em instrumento galvanizador do sentimento nacional na primeira metade do século XX. 
No final dos anos 1990 e início dos 2000, pesquisadores de São Paulo também procuraram relativizar o pioneirismo de Mário Filho na invenção de uma crônica esportiva moderna. O sociólogo Gilson Pinto Gil (1997), em trabalho defendido no Iuperj, por sua vez, adotou perspectiva convergente com os acadêmicos supracitados, ao referir-se aos relatos do jornalista pernambucano como historietas. Em sua análise, estas recorrem inúmeras vezes ao anedótico, tornando-se este procedimento estrutural em seu modo de narrar o passado futebolístico. O fato é que essa ambiguidade entre a história e a ficção, apontada por Gil com relação a Mário Filho, possuía antecedentes já na obra de Gilberto Freyre, sociólogo que cultivava essa dubiedade entre arte e ciência, o que dá insumos para o veto à aceitação da interpretação redentora esposada por $O$ negro no futebol brasileiro.

Entre todos os que adotaram uma perspectiva crítica, Antônio Jorge Soares foi o pesquisador que se dedicou com mais afinco à desmistificação do futebol brasileiro como uma tradição inventada por Mário Filho e avalizada por cientistas sociais contemporâneos, a partir de uma leitura não crítica da obra do jornalista pernambucano. Os "novos narradores acadêmicos", seguidores do viés de Mário Filho na abordagem do futebol, seriam avalizadores desta visão mistificadora. Em sua lista, o acadêmico aponta nomes como os de Joel Rufino dos Santos, Waldenir Caldas e Cláudia Mattos, entre outros (SOARES, 2001, p. 16). Pelas lentes iconoclastas de Soares, Mário Filho era assim uma espécie de inventor de tradições, em chave analítica negativa.

Dos autores mencionados por Soares, alguns replicaram as críticas sofridas e prolongaram um debate público em revistas científicas conceituadas. A discussão também chegou a render um livro coletivo "A invenção do país do futebol" - em que Ronaldo Helal e César Gordon Jr., parceiros de empreitada na organização do volume, fariam reparos a inconsistências teóricas constantes da tese de Soares, mormente a defasada concepção de história e de historiografia do autor, em nenhum momento definida pelo mesmo.

A nosso juízo, a obra acadêmica que percebeu com mais acuidade o significado do livro do jornalista pernambucano provém dos estudos literários e culturais. Intitula-se Mil e uma noites de futebol - o Brasil moderno de Mário Filho, de autoria de Marcelino Rodrigues da Silva. Sua contribuição advém do fato de evitar tanto as valorações laudatórias quanto as incriminatórias, com o devido cuidado para não incorrer em anacronismos na abordagem da obra. Em contrapartida, fez a opção mais serena e cautelosa, 
detendo-se no exame analítico interno da composição narrativa da obra, sem deixar de atentar às premissas contextuais da proposta autoral de Mário Filho, das fontes de que dispunha, do seu horizonte ideológico mais largo, numa palavra, do "espírito do tempo" em que viveu.

Por fim, convém pontuar que, na tentativa de refutar as condenações da obra de Mário Filho, o cientista político Luís Fernandes, valendose do prefácio à quarta edição do livro "clássico", endossa o pioneirismo historiográfico do jornalista: "Esta opção metodológica situa $O$ negro no futebol brasileiro como obra precursora do recurso sistemático à História Oral como fonte da História Escrita, prática que só viria a se disseminar mais amplamente nas Ciências Sociais brasileiras décadas depois." (FERNANDES, 2003, p. 10).

\section{A década de 1940 e o projeto jornalístico-literário de Má- rio Filho: uma leitura de Histórias do Flamengo (1945)}

Feita, na seção anterior, a apresentação da trajetória do jornalista; articuladas, conquanto sem mecanicismos, sua vida e sua obra; e expostas as apropriações apologéticas e desconstrutoras do livro $O$ negro no futebol brasileiro (1947) no jornalismo e na Academia, passamos agora ao exame de Histórias do Flamengo, obra que dá mais subsídios para avançar na compreensão das linhas mestras do pensamento de Mário Filho, corporificado em uma tetralogia publicada no decurso da década de 1940.

A pergunta inicial que se formula é: por que a escolha do Clube de Regatas do Flamengo? ${ }^{9}$ Cabe buscar entender a razão pela qual este clube em específico foi eleito por Mário Filho para integrar, na década de 1940, o seu projeto seriado de narração de uma história do futebol brasileiro. Em 1945, quando o clube faz 50 anos de fundação, vem a lume esta obra, que reúne uma série de crônicas escritas por Mário Filho desde o início daquela década,

9 Semelhante pergunta inspirou o título da tese de doutorado de Marizabel Kowalski Por que Flamengo?, defendida em 2001 no departamento de Educação Física da Universidade Gama Filho, sob orientação do antropólogo argentino Hugo Lovisolo, o mesmo orientador de Antônio Jorge Soares. 
com base em suas próprias reminiscências e em entrevistas feitas com personagens fundadores do clube. $\mathrm{O}$ mesmo método, diga-se de passagem, empregado na elaboração de $O$ negro no futebol brasileiro.

Em Histórias do Flamengo, sugestivamente intitulada no plural, Mário Filho conta a saga, as peripécias e os acontecimentos mais importantes da trajetória do Flamengo até então, inserindo inclusive como protagonista de vários casos ligados ao clube a figura do escritor e amigo José Lins do Rego. Para tanto, veja-se, por exemplo, o capítulo "Carnaval na Primavera", em que Mário Filho narra o sofrimento de José Lins do Rego durante a final entre Flamengo e Vasco, no Campeonato Carioca de 1944, ocasião em que o clube rubro-negro se sagrou tricampeão carioca pela primeira vez, de maneira dramática, com um gol de cabeça de Valido aos 44 minutos do segundo tempo (RODRIGUES FILHO, s/d).

Somado ao empreendimento renovador que se havia verificado no plano da linguagem e nas técnicas de reportagem, com a dinamização das matérias e o abrasileiramento de inúmeras expressões esportivas, Mário Filho tinha como meta também estimular a popularização e a nacionalização dos clubes brasileiros mais tradicionais, sediados na capital da República, que até o advento do profissionalismo em 1933 caracterizavam-se em sua maioria por uma postura aristocrática, seletiva e refinada, circunscrevendose em grande parte aos limites internos das fronteiras socioespaciais de suas agremiações, situadas na zona sul da cidade.

Decorrência da larga expansão que vinha sendo operada no futebol desde o início do século, o abrasileiramento clubístico constituía, por conseguinte, mais uma etapa a ser cumprida na evolução dos esportes e, notadamente, do futebol de clubes do país, devendo ser iniciada, como era de se supor, por uma agremiação do então Distrito Federal. Ao Estadonação, que reconfigurava suas bases na década de $1930 \mathrm{com}$ o processo de industrialização e urbanização do país, haveria de corresponder também um clube-nação, representante fidedigno e unificador dos torcedores dispersos por todo o país, conforme sugere o historiador da UFF Renato Coutinho em sua tese de doutorado, publicada em livro no ano de $2014^{10}$.

10 Para um debate acadêmico aprofundado sobre o Flamengo e a construção de um imaginário político nacionalista popular entre os anos 1930 e 1950, consultar o livro de Renato Soares Coutinho, fruto de sua tese de doutoramento. COUTINHO, 2014. 
Dessa maneira, era necessária a criação de tipologia entre os principais clubes da cidade, de modo a eleger um que pudesse cumprir a função de "clube-nação". O Flamengo será o clube eleito por Mário Filho para cumprir esse papel e essa missão.

Para tanto, o contraste primeiro na narrativa de Mário Filho se dá entre o Flamengo e o Fluminense e podia ser percebido em diversas instâncias. Uma delas se verificava na própria elaboração da história dos dois clubes. Assim como os 50 anos do clube da Gávea seriam comemorados com o lançamento do livro de Mário Filho, Histórias do Flamengo (1945), o cinquentenário do clube das Laranjeiras contaria também com a publicação de uma obra, História do Fluminense (1952), de autoria do escritor Paulo Coelho Neto, cuja família estava estreitamente associada à vida social e desportiva do clube.

Paulo era filho do escritor maranhense Henriques Coelho Netto, da Academia Brasileira de Letras, cuja biografia foi recentemente lançada por Leonardo Pereira (2018). Torcedor e dirigente tricolor, era conhecido por invasões de campo nas Laranjeiras, para interpelar o juiz sobre lanças da partida contra seu clube. Os dois irmãos de Paulo, Emanuel (Mano) e João (Preguinho), também participaram como jogadores, diretores e torcedores do Fluminense, dando nome hoje a ginásios com seus bustos em bronze nas dependências do clube.

Tal como aparecerá em O negro no futebol brasileiro, Mário Filho narra em forma de crônicas romanceadas os diversos casos recolhidos de sua própria recordação e de relatos orais de personagens históricos do Flamengo. $\mathrm{O}$ jornalista conseguira muitos destes relatos por intermédio de seu melhor amigo, José Bastos Padilha, antes mesmo que este se tornasse presidente do clube, que o apresentou a antigos sócios e a veteranos dos primórdios do clube, todos estudantes e atletas rubro-negros nos anos de 1910 e $1920^{11}$.

O contraponto estilístico entre os dois livros pode ser melhor avaliado através dos contrastes entre os comentários feitos por José Lins do Rego a Histórias do Flamengo e aqueles escritos pelo próprio Coelho Neto no preâmbulo ao seu livro:

11 De modo diverso, sem recorrer às relações clubísticas pessoais, Paulo Coelho Neto propõe-se à tarefa conspícua de pesquisa dos documentos e dos arquivos do clube, a fim de descrever com precisão factual e cronológica os marcos históricos do Fluminense, numa estrutura planejada e equilibrada que procurava inventariar os dados referentes a todos os esportes praticados no clube. 
"Mário Filho colheu de fontes autênticas o imenso e fabuloso cotidiano rubro-negro. Não permaneceu no elogio convencional, mas preferiu pôr nas ruas as nossas origens turbulentas, a nossa vida boêmia, a nossa têmpera de valentes. E por isto este livro tem, em certos trechos, aquele tom agreste dos A.B.C. dos nossos cantadores matutos. A língua e os fatos se confundem de tal maneira que autor e heróis parecem do mesmo team. O Flamengo, neste terrível ano de 1945, perdeu um tetra-campeonato; ganhou, porém, este livro de sua vida, que lhe vale como um troféu de bronze de primeira ordem." (REGO, 11/12/1945, p. 4)

"Orientei-me por um só guia: o arquivo do Fluminense, modelo de ordem e, sobretudo, de carinho não só de seus iniciadores os pioneiros da fundação -, como também dos continuadores até os nossos dias." (...) "O Fluminense, por intermédio de seu presidente, Dr. Fábio Carneiro de Mendonça, convidou-me para escrever, não 'uma história' nem 'histórias', mas a 'História do Fluminense'. E história é pesquisa, estudo e conhecimento dos fatos que se desenrolam através dos tempos." (...) "Cingi-me, tão-somente, aos acontecimentos. Coerente comigo próprio e com as tradições do Fluminense, preferi o gênero sóbrio, mas verdadeiro, de que Pedro Vaz de Caminha foi o iniciador em nossa história." (COELHO NETO, 1952, p. 9-11) ${ }^{12}$

Mário Filho, dois anos após ter publicado Histórias do Flamengo, continuaria sustentando a superioridade da pesquisa baseada em fontes orais sobre a pesquisa baseada em fontes escritas, no intuito de apreender e captar o real percurso histórico dos esportes no Brasil. Em O negro no futebol

12 Esta obra volumosa sobre o Fluminense teria seu desdobramento em 1969, quando Paulo Coelho Neto edita o segundo tomo do livro, dando continuidade, ano a ano, esporte a esporte, à descrição dos fatos mais marcantes da história do clube. A diretoria do Fluminense Futebol Clube viria ainda a relançar esta obra no ano do seu centenário (1902-2002), atualizando os dados que a pesquisa de Coelho Netto não chegou a cobrir. Embora Paulo Coelho Neto arvorasse, na citação acima, sua condição de pesquisador frio, ponderado e equidistante de seu objeto, apenas amparado nas fontes documentais do clube, o seu livro Fluminense pitoresco e dramático, também de 1969, seria escrito num tom anedótico e memorialístico muito próximo do estilo de Mário Filho. 
brasileiro (1947), após salientar a importância de buscar o contato com a privacidade e com a intimidade dos personagens do universo esportivo, como o acesso ao álbum de recortes e fotografias do goleiro Marcos Carneiro de Mendonça, contendo os fatos mais marcantes do futebol brasileiro entre 1910 e 1919, Mário Filho elencava, de cor, uma lista de mais de 65 entrevistados, entre as centenas de jogadores, dirigentes e torcedores que havia escutado.

Segundo o autor:

"Cada um deles me ajudando um pouco, mais do que os jornais, do que os livros de atas das entidades, de correspondência dos clubes, de súmulas dos jogos, de registro dos jogadores. Os documentos oficiais me mostraram que a história verdadeira se escreve de outro jeito. (...) Eu fui, aos poucos, levantando o véu, ouvindo daqui, dali, reconstituindo a tradição oral, muito mais rica, muito mais viva do que a escrita dos documentos oficiais, graves circunspectos, dos jornais que não dizem tudo." (RODRIGUES FILHO, 2003, p. 22 e 23) ${ }^{13}$

Mais do que meras divergências quanto a questões teóricas e metodológicas subjacentes à orientação de cada autor, as diferenças de estilo sinalizavam sobretudo para a oposição do perfil que se queria atribuir a cada agremiação. O Flamengo, nesse sentido, parecia enquadrar-se com maior precisão numa certa linhagem interpretativa de desenvolvimento do futebol brasileiro, repetindo de maneira homóloga o percurso histórico de popularização deste esporte no país.

De um ponto de vista sumário e esquemático, Mário Filho concebe a história do futebol da seguinte forma: inicialmente um esporte amador, de

13 Sob um prisma epistemológico e heurístico, a ser desenvolvido em outro artigo, pode-se dizer que enquanto Mário Filho imiscuía sujeito e objeto na investigação histórica e na trama narrativa da história de seu clube, Coelho Neto procurava ao máximo estabelecer as linhas divisórias e as barreiras que separavam o pesquisador do passado do clube; enquanto o primeiro, além de privilegiar o polo da subjetividade, apresentava-se como um contador de histórias, muito próximo do clássico narrador benjaminiano, o segundo norteava-se pelos critérios da objetividade e apresentava-se como o representante de uma concepção oficial e positiva para a realização de uma história dos esportes; enfim, enquanto Mário Filho recorria à oralidade e à memória, Coelho Neto sustentava a preeminência da escrita e das fontes documentais na reconstituição verídica do passado do seu clube. 
feição estrangeira, reservado à elite, que pouco a pouco vai sendo assimilado, traduzido e reinterpretado pelos seus praticantes e pelo público brasileiro, até que, com a adoção do profissionalismo na década de 1930 e o ingresso maciço de atletas negros, mestiços e provenientes das classes populares, o país cria um estilo original e autêntico de jogar.

Com o Flamengo, os fatos e a forma de contar a sua história seriam semelhantes. Iniciando-se em 1895 como um clube elitista e amador, ligado de maneira exclusiva ao remo, o Flamengo abre em 1911 sua seção de futebol, oriunda de uma dissidência de jogadores do Fluminense, malgrado o preconceito e a resistência que ainda grassava entre os antigos atletas e remadores do clube em relação à prática futebolística. Nas décadas de 1910 e 1920, ainda que com jogadores formados apenas por estudantes amadores e, por extensão, por filhos das famílias mais tradicionais do Rio de Janeiro, o time de futebol vai-se tornando popular no bairro e na cidade.

Segundo a argumentação de Mário Filho, isto se devia, entre outros fatores, à ausência de estádio próprio para treinar, o que ensejava a proximidade do jogador com o público no campo aberto e improvisado da rua do Russel (Id, 2003, p. 57), e ao espírito boêmio dos seus integrantes, que logo criariam a República Paz e Amor, local onde eram comemoradas de forma carnavalesca as vitórias no remo e no futebol: “... o time do Flamengo ia treinar, garotos de família, moleques, passavam a notícia de boca em boca. Quando os jogadores do Flamengo chegavam no Russel já encontravam gente esperando por eles". Acrescente-se ainda que a República Paz e Amor seria local também de residência de personagens históricos da cidade, como o carnavalesco K. Veirinha, que em 1918 fundaria o Cordão do Bola Preta (CASTRO, 2001, p. 38).

É oportuno fazer um parêntesis para ressaltar como desde aí, nos idos de 1910 e, em especial, de 1920, a combinação entre o futebol e o carnaval - forma preferida de festejar os títulos nas ruas e nos bares - será o critério mais destacado por Mário Filho no intuito de aferir e de conferir ao Flamengo a sua condição de popularidade. Era nas frinchas do discurso acerca da música brasileira, que se respaldava, legitimava e homologava o futebol como um esporte nacional-popular.

A contraposição entre o Flamengo e o Fluminense é novamente a base em que se ampara Mário Filho para estabelecer esta ponte e para ratificar seu postulado: 
"Emolduradas, as moças apareciam ofegantes, mas risonhas e felizes. Os garotos acompanhavam, em passo de marcha, como a uma banda marcial, o reco-reco do Flamengo. Juntava gente na calçada. Que era? Era o Flamengo. Ou os rapazes do Flamengo. E todos sorriam, satisfeitos da vida por aquela surpresa de fim de tarde de domingo morno, quase adormecido. O bloco rubronegro ia espalhando alegria pelas ruas afora até o Largo do Machado onde ficava, e ainda fica, hoje, ignorado, soturno, o Lamas, que era uma espécie, mal comparando, de um Moulin Rouge do remo e do futebol. (...) nesses domingos de recoreco, os jogadores do Fluminense, que também faziam ponto no Lamas, vinham para a porta, desciam à calçada, chegavam à rua para receber os jogadores e remadores do Flamengo. Talvez com vontade de entrar no cordão, coibindo-os, porém, um pudor ainda hoje bem Fluminense. (...) As vitórias do Fluminense eram comemoradas doutra maneira. Geralmente, com um jantar no Sul-Americano, um restaurante da rua da Assembleia, que não existe mais. Encomendava-se uns frangos ao leite e mandava-se arrumar as mesas em T. Quando a vitória era de campeonato o Fluminense fazia um corso, os carros de capota arriada, como se fosse domingo de carnaval, mas sem confete nem serpentina. Era uma passeata elegante, bem-comportada, bem-educada, como se dizia noutros tempos. Não era aquela algazarra do Flamengo, aquele carnaval, carnaval mesmo, fora de época" (RODIRUGES FILHO, s/d, p. 9 e 10)

A construção identitária, do plano nacional subsumido ao clubístico, passa por disputas de definição e de classificação, tais como apontadas pelo sociólogo Renato Ortiz:

“...a luta pela definição do que seria uma identidade autêntica é uma forma de se delimitar as fronteiras de uma política que procura se impor como legítima. Colocar a problemática dessa forma é, portanto, dizer que existe uma história da identidade e da cultura brasileira que corresponde aos interesses dos diferentes grupos sociais na sua relação com o Estado" (ORTIZ, 1985, p. 9). 
Destarte, mais adiante, Mário Filho volta a reiterar e legitimar o espírito carnavalesco que, para ele, se expressava de forma mais cristalina no Flamengo:

\begin{abstract}
"Quando acabou o jogo foi mesmo 3 a 2. Aí começou o Carnaval. Toda a cidade soube, sem rádio nem nada, na mesma hora, que o Flamengo tinha vencido. E como era o Flamengo, esperou-se pelo carnaval rubro-negro. Estava tudo preparado. Organizou-se um cortejo de automóveis, enorme, mais de 100 carros, como de corso da Avenida, com bandeiras do Flamengo cobrindo os capôs, as capotas arriadas, os jogadores sentados em cima, torcedores de pé no para-lamas queimando fogos de bengala para que se visse, de longe, a passeata triunfal do Flamengo." (Ibid, p. 18) (...) "Lembro-me que, numa noite de terça-feira de Carnaval, eu estava no Nice, à espera do préstito dos Democráticos, quando ouvi umas moças, hoje brotos, cantando 'Piranha eu sou de coração, Flamengo até debaixo d'água'. Aquilo me surpreendeu, como uma revelação. Um clube vinha para a música popular, era cantado no Carnaval. Então não me espantou mais uma certa arrogância do Flamengo. Porque não era à-toa que um clube virava marcha de carnaval, canção ou hino". (...) "E charangas tocavam o Flamengo, Flamengo, tua glória é lutar. De tarde, por causa do Flamengo, o Fla-Flu era um carnaval; de noite, um São João. O Flamengo trazia as festas mais populares para o futebol." (Ibid, p. 26 e 30)
\end{abstract}

A estratégia discursiva a que recorria Mário Filho para atribuir ao Flamengo uma magnitude e um elo com a "comunidade imaginada" da nação ${ }^{14}$ era, pois, a ideia de que, por meio deste clube, mais do que qualquer outro, efetuava-se aquela relação, para ele inextricável, entre a música

14 Termo consagrado pelo intelectual inglês Benedict Anderson, em obra homônima, do início dos anos 1980, acerca do debate pós-colonial asiático. Dentro de tal propósito, o autor descentrou a conceituação do nacionalismo, tal como posta em termos eurocêntricos, em favor de outra, mais abrangente em âmbito espacial e geográfico. Nela, advoga a preeminência dos meios de comunicação de massa na construção da identidade nacional ao longo do século XX, mostrando de que modo a construção da narrativa identitária ultrapassa a agência do Estado e é operada por discursos construídos por diferentes mídias, a exemplo do jornal, do rádio e da televisão. Cf. ANDERSON, B. (2008) 
popular e o futebol. Seja a têmpera boêmia de muitos de seus fundadores - lembre-se da República Paz e Amor -, seja a atuação de muitos de seus jogadores em campo - lembre-se de Leônidas da Silva - seja a comemoração de muitos de seus torcedores nas ruas, nos bondes e nas arquibancadas lembre-se de Jaime de Carvalho, criador da Charanga rubro-negra em 1942 - era o quesito musical e o espírito carnavalesco que imputava ao Flamengo sua índole popular frente aos demais clubes. Mais uma vez, nas fímbrias do discurso sobre o samba, o carnaval e a música, Mário Filho justificava e afirmava seu projeto esportivo na capital da República, irradiando-o em âmbito nacional.

Junto à música e ao contraste com o antípoda Fluminense, outra chave para o êxito do time carioca consistiu na importação dos ídolos de origem negra nos anos 1930, como Fausto, Domingos da Guia e Leônidas da Silva. Com isto, o Flamengo fazia uma espécie de "transfusão de popularidade" (Id., 2003, p. 209). Em reação a tal popularização, Mário Filho relata em Histórias do Flamengo que Oswald de Andrade disse-lhe certa feita, com sarcasmo, que, para ser noticiado e para ser conhecido no Brasil daquela época, era mister torcer para o Flamengo: “... hoje quem não está no football é um condenado à obscuridade. Por isso estou com vontade de apresentar uma proposta para ser sócio do Flamengo". (Id, s/d, p. 38)

Blagues à parte, é necessário afirmar tais fatos medida em que as hipóteses aventadas por Mário Filho (MURAD, 1996, p. 445) para explicar o vertiginoso crescimento de popularidade do Flamengo no país durante as décadas de 1930 e 1940, podem ser resumidas de forma esquemática em quatro itens: a) presença de pobres, negros e mestiços no time, com destaque no selecionado nacional, a exemplo de Fausto, Leônidas da Silva e de Domingos da Guia; b) transmissão radiofônica em escala nacional; c) o inédito tricampeonato de 1942-43-44; e d) treinamentos em campo aberto, proporcionando uma proximidade entre o torcedor - mais que o associado -, o jogador e o clube (Ibid).

A obra Histórias do Flamengo (1945) esgotava um cabedal de lembranças, amparadas em suas fontes de pesquisa oral, destacando uma miríade de anedotas, crônicas e casos pitorescos necessários à compreensão do significado do cinquentenário deste clube na história no futebol brasileiro. Originalmente pequeno, amador e aristocrático, o Flamengo tornara-se, segundo Mário Filho, em meio século de existência, um clube de projeção nacional, um clube-nação. Em tom ufanístico, seria ele "o mais popular", "o mais querido do Brasil", a encarnar as próprias vicissitudes de expansão 
deste esporte em todos os quadrantes do Brasil. Em um processo homólogo ao ocorrido com o futebol profissional brasileiro, o crescimento de popularidade do Flamengo confundia-se com a entrada de jogadores negros e mestiços em seu time.

A explicação para o crescimento do clube é estruturada em cinco partes, assim denominadas: "O Berço", "A Garagem", "O Café", "O Campo" e "Tipos do Flamengo". Esta última parte é entremeada por uma série de anedotas em torno de uma galeria de personagens que marcaram a vida social do clube em suas primeiras décadas. A título de exemplo, destaquese "Vai na Bola", apelido de Alfredo Pinto, torcedor lendário do Flamengo durante os anos de 1920 e 1930, conhecido por diversos sacrifícios em campos adversários, seja em Madureira, seja em São Cristóvão, seja no estádio do América.

Para conseguir assistir ao seu clube nos estádios da cidade, o torcedor apanhava dos rivais e acabava com frequência no Pronto Socorro. Segundo Mário Filho, foi o então goleiro do Flamengo, Yustrich, quem cunhou o apelido em função do torcedor passar os treinos e os jogos inteiros gritando para os jogadores do seu time a interjeição: “- Vai na bola!”. Ainda segundo Mário Filho, foi José Lins do Rego quem sugeriu o torcedor para entrar em campo com a equipe do Flamengo, batendo com os pratos de metal, o que valeu a eterna gratidão de Vai na Bola para com o escritor paraibano (RODRIGUES FILHO, s/d, p. 338).

Se com o Fluminense o contraponto se dava por meio da dicotomia aristocrático versus popular - oposição extensível ao Botafogo -, com o Vasco da Gama a estratégia dicotômica era o nacional versus o estrangeiro. O Vasco era visto como o clube dos imigrantes, dos portugueses, dos colonizadores, posto que fundado pela colônia lusitana em 1898. De acordo com Mário Filho:

“... o Lusitânia era mais português do que o Vasco. No Vasco entrava brasileiro, no Lusitânia não, só português. Influência da vinda de um escrete de Lisboa ao Rio. Surgiram logo três clubes da colônia: o Lusitânia Esporte Clube, o Centro Português de Desportos, o Lusitano Futebol Clube" ... "O Vasco, clube da colônia, seguia a boa tradição portuguesa da mistura”. (Id, 2003, p. 120) 
A disseminação de clubes na cidade e no subúrbio também era mencionada por Mário Filho, dando ensejo a essa tipologia que identificava o clube nacional-popular, o clube imigrante e o clube aristocrático. Mas a expansão do futebol ampliava ainda esse conjunto de agremiações clubísticas: "Em cada canto um time, um clube. Time de garotos, de moleques, clubes de operários, de gente fina. Mas muito clube, clube demais" (Ibid, p. 50). Destes, Mário Filho acrescenta assim um novo tipo-ideal, o clube operário, que tinha como representante o Bangu, homônimo da fábrica da zona oeste da cidade, aonde se chegava de trem.

Mário Filho, ao invés de escrever um novo tomo, fez com Histórias do Flamengo o mesmo que fizera com $O$ negro no futebol brasileiro em sua segunda edição de 1964: ampliou-o e atualizou-o em mais uma edição no início da década de 1960, sendo esta reeditada mais uma vez em 1966, ano de seu falecimento. Vale dizer a propósito que, ao contrário da diretoria do Fluminense, o Clube de Regatas do Flamengo não reeditou, nem prestou qualquer homenagem em seu centenário (1895-1995) à obra de Mário Filho, que recupera boa parte da memória das primeiras décadas de existência do clube.

Deve-se salientar, entretanto, a importância não só de Mário Filho na história do Flamengo como de boa parte de sua família. É de Milton Rodrigues, seu irmão, o filme Alma e corpo de uma Raça (1938), com registros da natação e das demais modalidades atléticas do Flamengo. No terreno da cinematografia, coube à família Niemayer a responsabilidade por criar e salvaguardar uma valorosa tradição de reportagem audiovisual sobre o futebol e o Clube de Regatas do Flamengo. O Canal 100, apresentado em forma de trailers nas salas de cinema carioca durante as décadas de 1960, 1970 e 1980, foi uma criação de Carlinhos Niemayer em 1959. Seu filho, Alexandre Niemayer, em 1999, quarenta anos depois, viria a dirigir Histórias do Flamengo, documentário homônimo ao livro de Mário Filho, contando com boa parte de imagens do acervo do Canal 100 (MURAD, 1996, p. 134). 
Assim, os "lugares de memória"15 narrados em Histórias do Flamengo vão buscar os espaços centrais do Rio de Janeiro de início do século XX. Além deles, são focalizados os pontos de sociabilidade específicos da cidade, a exemplo de a República Paz e Amor, o Café Rio Branco, a Garagem, o Estádio da Gávea. Estes seriam erigidos por Mário Filho em sua obra como locus decisivos na afirmação da identidade do clube e constituiriam a base inicial para a comprovação do caráter "nacionalpopular" do Flamengo a partir dos anos 1930, quando do desenvolvimento dos meios de comunicação, especialmente do rádio.

\section{Considerações finais}

O presente artigo teve por finalidade precípua situar o livro $O$ negro no futebol brasileiro (1947) com relação à produção bibliográfica de Mário Filho, em particular à publicação antecedente do jornalista, Histórias do Flamengo (1945). A motivação para isto decorreu tanto da amplitude de obra literária e esportiva, assinada pelo jornalista ao longo de quarenta anos de carreira no jornalismo quanto da recorrência quase exclusiva e monotemática de seu livro principal, em detrimento de outros, igualmente importantes e instigantes, via de regra esquecidos ou ofuscados.

Sendo assim, na primeira seção do artigo, procurei repisarinformações sobre a sua trajetória, tais como consagradas pelo meio jornalístico a partir dos anos 1990, especialmente o trabalho de divulgação da vida e da obra de Mário Filho empreendido por Nelson Rodrigues e Ruy Castro. Em seguida, articulei sua obra com o pensamento de dois companheiros nordestinos, de fundamental importância na configuração de seu ideário esportivo nacional em meados do século XX, Gilberto Freyre e José Lins do Rego, salientando a

15 Conceito atribuído nos anos 1980 ao historiador Pierre Nora, representante da terceira geração dos Annales e da Nova História. Nele, considera-se a materialidade da reconstituição histórica, através de monumentos e evocações dedicados à exaltação e à rememoração do passado, a exemplo das efemérides comemorativas do bicentenário da Revolução Francesa (1789-1989). As relações entre história e memória, defendidas por Nora, passam necessariamente por elementos materiais, simbólicos e funcionais que permitem ao conjunto da sociedade aceder ao seu tempo pretérito. 
interpenetração das ideias do trio. Por último, nesta seção, intentei apresentar as linhas de força das críticas formuladas pelo meio acadêmico à construção da imagem e da reputação de Mário Filho, em suas ambivalências como escritor, pesquisador e ficcionista.

Já a parte subsequente dedicou-se a investigar a série de publicações sobre a história e a memória do futebol nos anos 1940, quando Mário Filho compõe uma tetralogia, que atinge o ponto mais alto em $O$ negro no futebol brasileiro. Para contribuir à compreensão dessa obra-chave, recorri ao livro anteriormente publicado, Histórias do Flamengo, de 1945, a fim de entender como elementos narrativos da interpretação do fenômeno futebolístico no país já estavam colocados naquele trabalho prévio. Enquanto o livro de 1947 elege a temática do negro na sociedade e no futebol brasileiros, o de 1945 tem por escopo as origens e o desenvolvimento de um clube da capital da República.

Importa, para Mário Filho, narrar uma história clubística de progressiva popularização, nacionalização e de emancipação, com vistas a reconhecer no Flamengo os mesmos passos dados no desenvolvimento do futebol nacional, entre inícios do século XX e meados do século passado. $\mathrm{O}$ clube de regatas, de origens aristocráticas, transforma-se pouco a pouco em time de futebol, capaz de assistir a uma inflexão nos anos 1930, quando as transmissões radiofônicas contribuem para disseminar os times do Rio em âmbito nacional. O abrasileiramento clubístico é assim cumprido, por meio da integração de seus ídolos negros, de extração popular e proletária, contribuindo para dar os contornos argumentativos que seriam desenvolvidos de forma mais bem acabada e com maior repercussão em $O$ negro no futebol brasileiro.

Acredita-se assim que a releitura do conjunto da obra de Mário Filho é não apenas oportuna como fundamental para enquadrar seu livro mais conhecido em uma leitura abrangente, que revela o fôlego e a ambição do projeto deste jornalista esportivo, precocemente falecido em 1966, com menos de sessenta anos de idade.

Entende-se, sem embargo, que ainda há inúmeras questões a serem aprofundadas e complementadas para a interlocução acadêmica em futuros trabalhos. Estas não puderam ser aqui contempladas, em função do espaço disponível e dos limites de um recorte cabível em artigo científico: 1) É possível analisar $O$ negro no futebol brasileiro vis-à-vis outras obras de Mário Filho nos anos 1940, tais como Copa Rio Branco e Romance do futebol?; 2) Há um plano político mais amplo que englobe as duas obras de 
Mário Filho aqui examinadas, numa exegese coetânea e externa ao texto?; 3) É possível alvitrar a imposição de uma história do futebol no Rio de Janeiro, então capital da República, como narrativa irredutível e extensível ao futebol brasileiro como um todo, elidindo singularidades regionais?; e 4) Por fim, tal como sugerem pesquisadores da história do esporte e da mídia, a exemplo Rafael Fortes e Ronaldo Helal, não se superestima, por parte da imprensa e do meio acadêmico, o real alcance da obra $O$ negro no futebol brasileiro?

\section{Referências bibliográficas}

ANDERSON, Benedict. Comunidades imaginadas. São Paulo: Companhia das Letras, 2008.

ANTUNES, Martin Fátima. Com brasileiro, não há quem possa! Futebol e identidade nacional em José Lins do Rego, Mário Filho e Nélson Rodrigues. São Paulo: Editora UNESP, 2004.

CAMPOS ARAÚJO, José Renato de. "Imprensa e futebol". In: Futebol e imigração: o caso Palestra Itália. São Paulo: Editora Sumaré; IDESP, 2000.

CAPRARO, André. "Mário Filho e a invenção do jornalismo esportivo profissional”. In: Revista Movimento. Porto Alegre, v. 17, n. 2, 2011, p. 213224.

. SANTOS, Natasha; CAVICHIOLI, Fernardo; MEZZADRI, Fernando. "A crônica esportiva de José Lins do Rego: paixão, política e relações de força". In: Revista Brasileira de Educação Física e Esporte. Vol. 30, n. 2, 2016, p. 335-344.

CARNEIRO, Edison. "Apresentação à segunda edição". In: RODRIGUES FILHO, Mário. O negro no futebol brasileiro. Rio de Janeiro: Editora Civilização Brasileira, 1964.

CASTRO, Ruy. O anjo pornográfico: a vida de Nelson Rodrigues. São Paulo: Companhia das Letras, 1992.

(Org.). À sombra das chuteiras imortais: crônicas de futebol. São Paulo: Companhia das Letras, 1994. 
. (Org.). A pátria de chuteiras: novas crônicas de futebol. São Paulo: Companhia das Letras, 1994.

. O vermelho e o negro: pequena grande história do Flamengo. São Paulo: DBA, 2001.

COELHO NETTO, Paulo. História do Fluminense. Rio de Janeiro: s.e., 1952.

COUTINHO, Renato Soares. Um Flamengo grande, um Brasil maior: o Clube de Regatas do Flamengo e a construção do imaginário político nacionalista popular (1933-1955). Rio de Janeiro: Editora 7Letras, 2014.

COUTO, Cristiano. "Encontros com a Civilização Brasileira: resistência cultural e prenúncio de uma nostalgia (1978-1982)". In: Revista Dimensões. N. 29, 2012, p. 351-373.

FERNANDES, Luís. "Futebol, racismo e identidade nacional". In: RODRIGUES FILHO, Mário. O negro no futebol brasileiro. Rio de Janeiro: Mauad, 2003.

GIL, Gilson Pinto. Humildes, mascarados e gênios: ética, história e identidade nacional na obra de Mário Filho. Rio de Janeiro: Tese de doutorado/IUPERJ, 1997.

HAAG, Fernanda Ribeiro. "Mário Filho e $O$ negro no futebol brasileiro: uma análise histórica sobre a produção do livro". In: Revista Esporte \& Sociedade. Rio de Janeiro: ano 9, n. 23, março de 2014, p. 1-23.

HOLLANDA, Bernardo Borges Buarque de. O descobrimento do futebol: modernismo, regionalismo e paixão esportiva em José Lins do Rego. Rio de Janeiro: Edições Biblioteca Nacional, 2004.

KOWALSKI, Marizabel. Por que Flamengo? Rio de Janeiro: Programa de Pós-Graduação em Educação Física/ Universidade Gama Filho, 2001.

LOPES, José Sérgio Leite. "A vitória do futebol que incorporou a pelada". In: Revista USP. São Paulo: nº 22, 1994, p. 64-83.

MONTENEGRO, Olívio. "Uma história de football”. In: Jornal dos Sports. Rio de Janeiro, 15 de julho de 1948.

MURAD, Maurício. Dos pés à cabeça: elementos básicos de sociologia do futebol. Rio de Janeiro: Irradiação Cultural, 1996. 
ORTIZ, Renato. Cultura brasileira e identidade nacional. São Paulo: Brasiliense, 1985.

PEREIRA, Leonardo Affonso de Miranda. Footballmania: uma história social do futebol no Rio de Janeiro: Nova Fronteira, 2001.

QUEIROZ, Maria Isaura Pereira de. "O football e o caráter dionisíaco do brasileiro". In: Jornal dos Sports. Rio de Janeiro, 24 de julho de 1948.

REGO, José Lins do. "Opiniões sobre Histórias do Flamengo". In: Jornal dos Sports. Rio de Janeiro, 11 de dezembro de 1945.

. "Romance do football". In: Jornal dos Sports. Rio de Janeiro, 7 de janeiro de 1950.

RODRIGUES, Nelson. "O homem fluvial”. In: FILHO, Mário Rodrigues. $O$ sapo de Arubinha: os anos de sonho do futebol brasileiro. São Paulo: Companhia das Letras, 1995.

RODRIGUES FILHO, Mário. Copa Rio Branco, 32. Prefácio de José Lins do Rego. Rio de Janeiro: Pongetti, 1943.

. Histórias do Flamengo. Rio de Janeiro: Gernasa, s/d.

. Romance do football. Rio de Janeiro: Pongetti, 1949.

. Viagem em torno de Pelé. Rio de Janeiro: Editora do Autor, 1963.

. O rosto. Prefácio de Antônio Olinto. Rio de Janeiro; São Paulo: Record, 1965.

. A infância de Portinari. Prefácio de Nelson Rodrigues. Rio de Janeiro: $\overline{\text { Bloch, }} 1966$.

. O negro no futebol brasileiro. Prefácio de Gilberto Freyre. Rio de Janeiro: Mauad, 2003.

SILVA, Marcelino Rodrigues da. As mil e uma noites do futebol: o Brasil de Mário Filho. Belo Horizonte: Editora UFMG, 2006.

SOARES, Antônio Jorge. Futebol, raça e nacionalidade no Brasil: releitura da história oficial. Rio de Janeiro: Tese de Doutorado em Educação Física da Universidade Gama Filho, 1998. 
. "História e a invenção de tradições no futebol brasileiro". In: HELAL, Ronaldo; SOARES, Antônio Jorge; LOVISOLO, Hugo. A invenção do país do futebol: mídia, raça e idolatria. Rio de Janeiro: Mauad, 2001.

SODRÉ, Nelson Werneck. "Sociologia do esporte". In: Jornal dos Sports. Rio de Janeiro, 8 de julho de 1948.

SOUZA, Denaldo. O Brasil entra em campo! Construções e reconstruções da identidade nacional (1930-1947). São Paulo: Annablume, 2008.

TOLEDO, Luiz Henrique de. Lógicas no futebol. São Paulo: Huicitec; FAPESP, 2002.

Relatos orais - MIS-Rio - Museu da Imagem e do Som do Rio de Janeiro

MÁRIO FILHO - Série Depoimentos. Rio de Janeiro, 29 de Janeiro de 1969.

RECEBIDO EM: 05/05/2019

APROVADO EM: 05/08/2019 